ket for linjer og forbindelser mellem forfattere og kunstnere og kunne blive til en interessant udstilling (det er kun en del af billedmaterialet, der er gengivet), men efterlader også læseren med stor usikkerhed. Hvor signifikante er motiverne i de kvindelige kunstneres samlede produktion i perioden? Er bevægelsen fra krop og sprog mod kosmos kun til stede hos kvindelige kunstnere? Hvad med de historiske linjer? Og hvor vil Eva Pohl selv placere sin tilgang i forhold til de sidste snart 50 års kvinde- og kønsteorier? Bogen insisterer stædigt-suverænt på et særligt kvindeligt erfaringsrum og en særlig kvindelig tilgang til kunsten, der er langt fra dagens blanding af performativitetsteori og mulig ny feministisk materialisme, men man savner konturerne af en dialog med andre tilgange til stoffet. Der er interessante iagttagelser af f.eks. Franziska Clausens brud med de rette linjer, som Piet Mondrian bedrev dem, og her mærker man afsættet til en analyse af kvindelige kunstneres samspil med samtidens ismer, en kontekstualisering af deres valg og særpræg, som ellers generelt er fraværende.

Bogens berettigelse er dens øjenåbnende beskrivelse af motiver i kvinders kunst, der forklarer deres blik på liv, kunst og verden som et perspektiv, der strækker sig og forbinder kroppen og universet. Dens begrænsning er den flimrende, associerende tilgang, der gør det vanskeligt for læseren at hitte rede i selektioner og forbindelseslinjer. Et lyst værelse efterlader mange spørgsmål, og et væsentligt er, om den for alvor bliver det politiske argument, som den gerne vil være for et nyt syn på og en ny vurdering af kvindelige kunstnere, der kunne revidere deres placering i kunsthistorien.

Anmeldt af Anne Birgitte Richard

\title{
Nyere dansk litteraturhistorie til udlandet
}

Anne-Marie Mai: Danish literature in the 20th and early 21st century. Odense: Syddansk Universitetsforlag 2017, 278 sider.

Forsiden på Anne-Marie Mais engelsksprogede præsentation af dansk litteratur i den 20. århundrede og lidt til prydes af en håndfuld børn, der kravler rundt på H.C. Andersen-statuen i Central Park i New York. Et stykke dansk litteratur midt ude i den store verden og vel sagtens indbegrebet af denne litteratur. Man kan betragte bogen som et forsøg på at udvide denne opfattelse fremefter. Den er så at sige et opgør med sin egen forside. Og et meget kompetent opgør, kan jeg lige så godt røbe med det samme.

Bogen er, som Anne-Marie Mai selv nævner i indledningen, skrevet på baggrund af hendes store arbejde med det 20. århundredes danske litteratur, især redaktionen af Danske digtere i det 20. århundrede I-III, hvor man finder fyldige efterskrifter til hver bind, og hendes danske litteraturhistorie, Litteraturen finder sted I-III. Man kunne tilføje hendes nyeste udspil Galleri 66. En historie om nyere dansk litteratur. Især de to sidste eksperimenterer med at skrive anderledes litteraturhistorie, det 
være sig med udgangspunkt i litterært betydelige steder eller ud fra et bestemt årstal. I forhold til disse forsøg på at gøre op med den kronologisk fortalte, behørigt dækkende og kausalt forbundne litteraturhistorie er den engelsksprogede mere forsigtig. Der tilkendegives godt nok en inspiration fra nyhistorismen og Paul Riceour, men den er dråbevis. I det store hele er det litteraturhistorie as usual: en fortælling delt op i tidsintervaller og diverse grupperinger som forsøger at få det meste med, herunder ikke mindst at balancere værk- og forfatterskabsbeskrivelser med historisk baggrund. Det er et valg, som jeg formoder, har at gøre med bogens sigte. Den skal kunne fungere som en præsentation af dansk litteratur for de uindviede og måske også som lærebog for engelsklæsende studerende i dansk litteratur.

Som sådan kan den kun anbefales. Den er stofrig. Man er ikke et øjeblik i tvivl om, at forfatteren kan sine sager og meget mere til. Den er også godt struktureret. Til tider måske lidt vel opremsende, men ellers. Der er masser af fine indsigter i og kombinationer af værker og forfatterskaber og ikke mindst den stadige opmærksomhed for tidsskrifter og dermed miljøer, den sikre indplacering (og kanonisering) af mange kvindelige forfattere samt det relativt brede litteraturbegreb taler alt sammen til bogens fordel. Farvefotografierne er mere end flotte og garanterer den binding til stedet, som udgjorde grundideen i Litteraturen finder sted. Man får hvad man med rimelighed kan forlange, hvis man vil skaffe sig et overblik over dansk litteratur i bemeldte tidsrum.

Bogen er komponeret i tre dele, som svarer til bindene i Danske digtere $i$ det 20. århundrede: "Into the modern" (1900-1940), "Out of the real" (1940-1970) og "Through the wall" (1970-2015). Titlerne er i sagens natur grove generaliseringer. Ideen er, at erfaringen af storby- og industrimoderniteten omkring Anden Verdenskrig afløstes af andre og mindre socialt orienterede strømninger for igen af skifte til, hvad Anne-Marie Mai kalder det formelle gennembrud, et begreb hun møntede i den sidste af efterskrifterne til Danske digtere i det 20. Århundrede. Her er begrebet, måske som en håndsrækning til sit udenlandske publikum, suppleret med betegnelsen postmoderne. Altså det postmoderne formelle gennembrud. Men faktisk går der en anden periodeinddeling på tværs af bogens tredeling, én som forvirrer billedet en smule. I den lettere udvidede historie om nyere dansk litteraturhistorie er det nemlig 1870 og 1970, som skiller vandene. Modellen er klassisk dialektisk efter Hegel og Brandes. Det moderne gennembrud, altså 1870, reagerede imod og frigjorde sig fra 1800-tallets institutioner med splittelse og fremmedgørelse til følge, indtil det postmoderne formelle gennembrud omkring 1970 indoptog samtlige forudgående traditioner i sig i en frigørende syntese. Deloverskriften "Through the Wall" sigter således ikke kun til Berlinmuren, den er faktisk perifer, men til den i bogens optik virkelige rystelse, som er dette andet gennembrud. Det runger til gengæld igennem hele fremstillingen.

Man kan undre sig over, hvorfor denne anden og tilsyneladende mere tvingende opdeling ikke er ført helt igennem i bogens komposition. Det kunne have provokeret til en mere grundig refleksion over de historiske forandringer, som ligger til grund for det æstetiske brud omkring 1970. Jeg vil sådan set gerne købe ideen om, at tresserne, her er vi nødt til at begynde, og noget af det, der fulgte, afsatte et markant skel. Tresserne var det 20. århundredes mest moderne årti. Det åbnede en mængde 
af mulige kunstneriske veje og førte mange af dem ud i deres yderste konsekvens. Men så må vi for det første have en distinktion imellem de historiske forandringer, som betegnes ved hjælp af begreber som modernitet og postmodernitet, og så de mange og modstridende æstetiske strategier for at lave kunst inden for disse perioder, og for det andet diskutere os frem til mere holdbare formuleringer af, hvad det så er, der udmærker den kunst, som opstod af dette sidste brud. For det er som sagt her, det brænder på.

Hvis det højeste en litteraturforsker kan håbe på, er én god idé, som kan bære igennem, så er det i Anne-Marie Mais tilfælde ideen om det formelle gennembrud. Det er ikke hendes alene, men det er en vigtig idé. Jeg mangler bare stadig at få det ordentligt forklaret. Tilføjelsen af det umedgørlige begreb postmoderne, gør det ikke lettere. Dengang i Danske digtere i det 20. århundrede hed det, at perioden fra halvfjerdserne var et hidtil uset eksperimentarium. Som om litteraturen ikke altid eksperimenterede med sin form, og som om tresserne, det eksperimenterende årti om noget, blot var en forøvelse. Nu er det argument vistnok forladt. I stedet får vi at vide, at det er en øget åbenhed mellem forfatter, læser og værk, som er det nye. Men hvorfor så kalde det et formelt gennembrud? Andre bestemmelser tilføjes med løs hånd hen ad vejen, typiske postmoderne træk som samtidighed i forhold til traditionen og udjævning af skellet imellem kunst og populærkultur. Men det gør ikke ligefrem billedet klarere. Argumentet for de omtrentlige bestemmelser er rummelighed, men jeg har svært ved at se fordelen ved et begreb, der er så bredt, at det kan indeholde alt, men samtidig alligevel kvalificeres med en betegnelse som 'formel', som aldrig rigtig begrundes.

Anne-Marie Mai har sammen med andre mindet om, hvordan mange kunstnere i tresserne oplevede, at det, de lavede, stod i stærk opposition til modernismen. De genoplivede avantgarden, frigjorde kunsten ved at vælte det store Ki kunst omkuld, punkterede, hvad der for dem var krise- og skredretorikkens forkrampede og rygvendte patos, og slog hul ud til det, der nu gik for sig derude i livet af stort og småt. Disse lag på lag af virkelighed, som Patti Smith siger i dokumentaren Dreams of Life. Det skete i mange former fra et grænseløst spruttende free style-parlando over cool pop til systemisk konceptualitet. Anne-Marie Mai har i den forbindelse bidraget væsentligt til et tiltrængt skred i smagen. Men hvad det så lige er, smagen er skredet over i, er tilsyneladende stadig en udfordring at formulere. Det er det blandt andet, fordi dette skred, hvor vidtrækkende det end var, langt fra præger hele den efterfølgende periode. Meget af det, der fulgte, virker på mange måder mindre radikalt, end hvad der skete i tresserne, og trak da også på andre traditioner. Der er med andre ord en fare for at gøre modernismefortalernes fejl om igen ved at knæsætte en særlig type litteratur som den dominerende og forlænge den helt frem til i dag. Og så hjælper det ikke med den anden hånd at påstå, at der er rum for alt, når man nu med den ene har påkaldt sig en bestemt litteratur som den banebrydende. Det er derfor, jeg efterlyser en mere grundig diskussion af, hvad der er historiske, og hvad der er æstetiske forandringer og af forskelligheden imellem de sidste.

En anden udfordring, som også ligger og lurer under bogens litteraturhistoriske konstruktion, kommer fra netop modernismen. Den strejfes et par gange undervejs. Anne-Marie Mai er ikke glad for den historieskrivning, som ser modernismen som 
halvt modus og halvt genkommende strømning, én der rækker fra Ewald, Baggesen og Staffelt over Jacobsen, Claussen og Jensen til ikke mindst Højholt. Den bygger på en forestilling om, at disse digtere formulerede beslægtede erfaringer af moderniteten. Den trækker også på en verdenslitterær tradition, som ikke mindst inkluderer Jena-romantikken, fransk symbolisme og svensk og finlandssvensk lyrik fra Södergran til Ekelöf, alle sammen miljøer og strømninger som også er vigtige for mange postmoderne digtere heriblandt to for Anne-Marie Mai så centrale skikkelser som Peter Laugesen og Klaus Høeck. Problemet synes at være, at denne kongerække giver for megen status til den mere snævre og periode-baserede danske modernisme, som Anne-Marie Mai med rette synes har været for dominerende, men også at den bevæger sig frit og uforfærdet på tværs af både 1870 og 1970 og derfor synes at underminere enhver periodisering, herunder den for hende så vitale modsætning mellem de tidlige og de sene tressere. Det får blandt meget andet den konsekvens, at Sophus Claussen retraditionaliseres. Han er nu igen bare én blandt flere mystikere først i århundredet. Gjorde man ham til en digter, som formulerede radikale modernistiske indsigter, ville det jo være at spille fjenden et kort på hånden. Johannes V. Jensen uskadeliggøres også. Han får godt nok en central plads som indgang til hele fremstillingen, men det er som forfatteren til den historiske roman Kongens Fald. Bevares, bogen er da sprogligt eksperimenterende, men Mais Jensen vender ansigtet bagud.

Det kunne antyde, at udfordringen ikke bare er at formulere gennembruddet i tresserne og halvfjerdserne og dets efterdønninger bedre, men at det er selve ideen om at skrive litteraturhistorie ved hjælp af perioder, som kommer til kort. Hvis man nu i stedet for - og helt i tråd med både globalisering, medialisering og det bedste af nyhistorismen - tænkte litteraturhistorien i netværk og tog den idé om knudepunkter, som Anne-Marie Mai tidligere har arbejdet med, alvorligt, så kunne man måske forene de lange stiplede linjer mellem stærke beslægtede miljøer med mere lokale konfrontationer som den mellem modernister og postmodernister i tressernes Danmark. Så slap man for disse altid utilstrækkelige definitionsfors $\varnothing \mathrm{g}$ med deres uhensigtsmæssige demarkationslinjer, uden at man af den grund mistede blikket for opgør og grupperinger. Smagskampen kunne stadig føres, men denne gang uden invaliderende hjælpekonstruktioner på langs med litteraturhistorien. Og også uden man behøvede at give køb på de historier, som Anne-Marie Mai taler så varmt for i bogens indledning. Man kan sagtens fortælle historier om litteratur, men måske ikke Den store Fortælling om dansk litteratur i det 20. århundrede. Det vidste både postmodernisterne og nyhistoristerne, og det har Anne-Marie Mai som sagt selv forsøgt sig med så sent som i Galleri 66.

Alternativet til de mange fortællinger er ikke Den store Fortælling, men den stærke fortælling. Den sidder Anne-Marie Mai med nøglerne til, fordi hendes idé om, hvad der skete omkring 1970 (eller skal vi ikke en gang for alle blive enige om at sige tresserne?), er en stærk tese, uanset hvor vanskeligt det er at definere den i periodetermer, og også selvom den som alle stærke teser kan modsiges. En af grundene til, at bogen hverken går til den ene eller den anden yderlighed, er sikkert, at dens pædagogiske sigte kommer i vejen for dens litteraturhistoriografiske råderum. Litteraturhistorie er en formidlingsgenre, og der er efterspørgsel på 
overblik. Sådan et, og et yderst kundskabsrigt et, er nu foræret til interesserede udenlandske læsere. Det står dem herefter frit at kravle rundt på, hvad der er meget mere end en eventyrdigter.

Anmeldt af Dan Ringgaard

\section{Verdenslitteratur i Frankrig}

Mads Anders Baggesgaard, Nye franske verdener. Aarhus Universitetsforlag, Verdenslitteratur 5, 2016, 292 sider.

Globaliseringsbegrebets indtog i forskningsmiljøerne har tilføjet litteraturhistorien en ny dimension, som i de komparative litteraturvidenskaber særligt har kunnet aflæses i udviklingen af feltet verdenslitteratur. Det er fra dette ståsted, Mads Anders Baggesgaard i femte bind i Aarhus Universitetsforlags Verdenslitteratur-serie indleder sin afsøgning af globaliseringens aftryk og udtryk i nyere fransk litteratur. Udgangspunktet er en konstatering af, at Frankrig er et land i dyb krise. Stillet over for globaliseringens forandringer og det engelske sprogs dominans leder forfattere og intellektuelle i den tidligere politiske og kulturelle stormagt efter nye måder at forstå sig selv i verden på, og bogens projekt er at undersøge, hvordan dette reflekteres i litteraturen.

De to første kapitler forankrer problemstillingen i henholdsvis det empiriske og det teoretiske felt. Frédéric Beigbeders Un roman français fra 2009 bruges til at anskueliggøre den indledende diagnose om et kriseramt folk, der har tabt to krige og et kolonirige uden at bearbejde det, og som sidenhen har solgt deres sjæl til den globaliserede kapitalisme, hvor kulturen kun gives to overlevelsesmuligheder: enten som kulturarv eller som markedsprodukt.

Globalisering ses som en proces, der "skaber inter- og transnationale netværk og forbindelser på en række forskellige niveauer" (s. 30), og netop forskelle i niveau og perspektiv er en central udfordring for en litteraturhistorie, der har som mål at forbinde værkets mindste dele med dets globale indlejring. Baggesgaard finder inspiration hos en række af de seneste ti-tyve års markante litteraturhistorikere som f.eks. Emily Apter, Pascale Casanova, David Damrosch, Franco Moretti og Gayatri C. Spivak, men vedkender sig også indflydelse fra filosofien og New Historicism, der retter opmærksomheden mod andre diskurser end de rent litterære.

På den baggrund formuleres et ambitiøst projekt, der ved at forbinde en række niveauer og dobbeltheder - dansk/fransk, national/global, tekst/kontekst, litterære/ metalitterære diskurser, fransk/frankofon - sigter mod at give et bud på, hvordan der kan skrives litteraturhistorie i dag. Det lykkes over lange stræk i bogen, der i øvrigt præsenteres smukt og indbydende med et detaljeret noteapparat, en fyldig biografi og som prikken over i'et en række fine og velvalgte illustrationer af kupler, glober, sfærer og himmelrum.

Bogen falder i to hoveddele, hvoraf den første, "De franske og verden”, opererer med stor distance til de litterære værker. Her trækkes med fint overblik linjerne i den 